H. V. Korkach, PhD, associate professor, E-mail: kor2007@ukr.net https://orcid.org/ 0000-0002-9147-5508, ResearcherId: E-9765-2016

E.G. Iorgachova, Dr. of technical science, professor, E-mail: iorgachova@gmail.com https://orcid.org/0000-0003-3390-1756, ResearcherId: F-1132-2016

O.M. Kotuzaki, Ph.D, associate professor, E-mail: elena1kotuzaki@gmail.com https://orcid.org/ 0000-0001-9846-5508, ResearcherId:F-5106-2016 Odessa National Academy of Food Technologies, 112, Kanatna Str., Odessa, 65039, Ukraine Tel. +380636997012

\title{
MODIFICATION PROPERTIES OF CONFECTIONARY FLOUR PRODUCTS WITH SYNBIOTIC
}

\begin{abstract}
One of the main directions in the confectionery industry is creating new functional-purpose products. Besides meeting the dietary demand, they are supposed to be wholesome and health-giving. That is why so topical a task is enriching the composition of confections with synbiotics. They will have a positive effect on the manufacturing technology and impart physiological properties to final products.

The paper studies how the synbiotic complex consisting of a synbiotic (microencapsulated bifidobacteria in a pectin matrix) supplemented with a prebiotic (inulin) determines changes in the structural and mechanical properties of flour confections, in particular, of fatty fillings for wafer biscuits. The mass fraction of inulin has been established after introducing 10,20, and $30 \%$ of it into the filling to replace the equivalent amounts of fat. The quantity of bifidobacteria included in the recipe was determined considering the fact that in functional-purpose products, the physiologically active level of microorganisms should amount to $10^{6}-10^{7} \mathrm{CFU} / \mathrm{g}$ of the intestinal contents.

It has been studied how the synbiotic effects on the structural and mechanical properties of the fatty filling: its effective viscosity, adhesive strength, critical shear stress, and density. It has been found that introducing the synbiotic into the fatty filling and increasing the proportion of inulin adds to the effective viscosity in the test samples of the filling. Besides, the synbiotic makes the samples of filling stronger, which reduces the maturation time of wafer blocks. Thus, in the control sample, the blocks rest for $14 \mathrm{~min}$, but in the test samples containing 10, 20, and 30\% of inulin, this time is reduced to 12,8, and 6 min respectively. With an increase in the mass fraction of inulin, the specific pull-off force has been established to decrease, as compared with the control sample.

Experimentally, it has been revealed that there is dependence between the wafer filling density and the air phase characteristics (the size and number of air bubbles in the filling). It has been determined that the higher the density of the filling, the fewer air bubbles there are in the samples. The experimental findings prove that using the synbiotic in the wafer technology is practical.
\end{abstract}

Key words: flour confections, microencapsulated bifidobacteria, inulin, synbiotic complex, fatty filling, structural and mechanical properties, wafers.

\section{Introduction}

A lot of diseases in today's Ukraine are caused by imbalance of microflora inside the body, which results in various forms of dysbiosis. Besides overgrowth of intestinal pathogens, a general decrease in the body's immunity is observed. These disorders can be prevented and treated not only by using drugs, but also by supplementing the diet with foods containing probiotics, prebiotics, and synbiotics. In recent years, the latter have been used as functional food ingredients, since they have a synergistic effect on a person's living functions and overall metabolism [1].

Traditionally, the Ukrainians consume flour confections (FC) like sweet pastries, wafers, biscuits, cupcakes, muffins, hardtack, crackers, rum babas, cakes, and tortes. In this wide range of products, wafers are the most popular ones. They have a high calorific value, though are low in vitamins, complete proteins, and fibre. Wafer biscuits manufactured industrially can have fondant, nut, chocolate, praline, or fatty fillings. Wafer biscuits with fatty fillings make up the largest group (about $80 \%$ ) of all wafer products due to their inexpensiveness and good consumer properties. The filling is highly responsible for the formation of the flavour and aroma of wafer products, since its proportion in them can amount up to $70 \%$. So, it largely determines their quality, production cost, and shelf life.

\section{Review of literature}

Throughout the world, researchers look for functional ingredients that could be added to the composition of foods (in particular, to confections) in order to impart certain useful properties to them. Thus, in the paper [2], the scientists suggested including oat bran, as a functional ingredient, in the composition of wafers. This is supposed to help obesity, overweight, and diabetes.

The researchers [3] considered whether shortenings could replace fats to make wafer fillings more consumer-appealing.

Studies by the Ukrainian scientists [4-6] are concerned with developing technologies to produce wafers of enhanced nutritional and biological value, in particu- 
lar, those for particular nutritional use and dietetic nutrition. To make wafer biscuits more nutritious and biologically valuable, D. Fedorova in her work [7] suggests enriching them with semi-processed vegetable and fish products and plant components. T. Lozova [8] studies how to enhance the nutritive and biological value of wafer biscuits with fatty fillings that include unconventional raw materials in their formulations.

Ye. Polyvanov [9] focused on developing a technology of low-calorie wafer fatty filling that involved replacing sugar with sweet extract from stevia leaves mixed with erythritol. He proved that it was practical to control the amount of dry matter by introducing non-fat milk whey powder as a raw ingredient. Besides, he showed the possibility of adding $\beta$-carotene as a colourant, and ascorbic acid as a stabiliser of wafer fatty fillings.

The Russian researchers [10] considered reducing the fat and sugar content of a semi-processed product (fatty filling for flour confections) and making it functional-purpose by replacing all the sugar in its formulation and introducing prebiotics.

The Russian scientists [11] suggested using semifat sunflower flour for confectionery. They determined and tested the parameters of manufacturing fatty filling for wafers using this flour in the amount of $18 \%$ of the finished product's composition. Besides, they proved that the flour positively effects on the functional, sensory, and technological properties of the filling and finished products. The paper [12] suggests and gives reasons for adding protein to the composition of glazed wafer biscuits with fatty filling. The additive consists of a milk protein concentrate combined with a milk whey protein concentrate. Besides, it is suggested to replace $100 \%$ of the product's sugar with sugar substitutes (maltitol, isomalt).

However, no researcher has sought to develop a wafer product to help disorders of intestinal microbiocoenosis. That is why today's topical technological challenge is to create low-calorie functional confections made from a combination of raw material components. These products are supposed not only to be highly nutritive, but also to have a health-promoting effect on the body: they should maintain the natural balance of the intestinal microbiota, normalise it, and stimulate the body's protective function. It will also prove useful to include synbiotics in the formulation of fatty filling for wafers and study how they change its structural and mechanical properties, so as to obtain high quality products.

\section{search \\ Purpose and objectives of the re- \\ The purpose of the research is study-} ing how the synbiotic complex affects the mechanostructural properties of fatty filling for wafer biscuits.

To this end, the following objectives were set:

- to determine the mass fraction of inulin and probiotic microorganisms for the synbiotic complex to be developed;

- to study the effect of the synbiotic on the viscous, penetrometric, and adhesive properties of the fatty filling;

- to determine the change in the density and to study the distribution of air bubbles in the fatty filling samples.

\section{Materials and methods of the research}

The following raw materials were used in the experiments: inulin (Frutabit), low-ester apple pectin (Felizata, Ukraine), bifidobacteria (Bifidumbacterin by Biopharma and Bifidobacterium bifidum-1 from the collection of the Museum of Microorganisms at the Department of Biochemistry, Microbiology, and Nutrition Physiology, ONAFT), calcium chloride (State Standard (GOST) 450-77).

The viscosity of the fatty filling was measured with a rotational viscometer Rheotest 2 [13]. The results received were processed according to the instrument's manual.

The strength of the semi-finished product was measured with a penetrometer AR-4/7 by plunging the indentor (the cone), made of a certain material, with specified size, weight, and temperature, during a certain period of time [13].

The adhesive tension was measured by pulling the wafer sheet off the structured body (fatty filling) on the installation developed at ONAFT (Department of Bread, Confectionery, Macaroni Products, and Food Concentrates Technology) [13].

The density of the fatty filling was determined volumetrically [13].

Determination of the air phase. The air phase of the filling was quantified and qualified by microscopic examination. The method consists in determining the number and sizes of the air bubbles. To do this, a droplet of the filling is placed on the microscope slide, covered with the cover slip, and kept for 4 min pressed with a 500 $\mathrm{g}$ load. This smear preparation is then studied under a microscope at 120x magnification. The bubbles counted are those within the field of vision $800 \times 800 \mu \mathrm{m}$.

\section{Research results}

The previous papers $[14,15]$ proved the practical importance of developing a synbiotic complex consisting

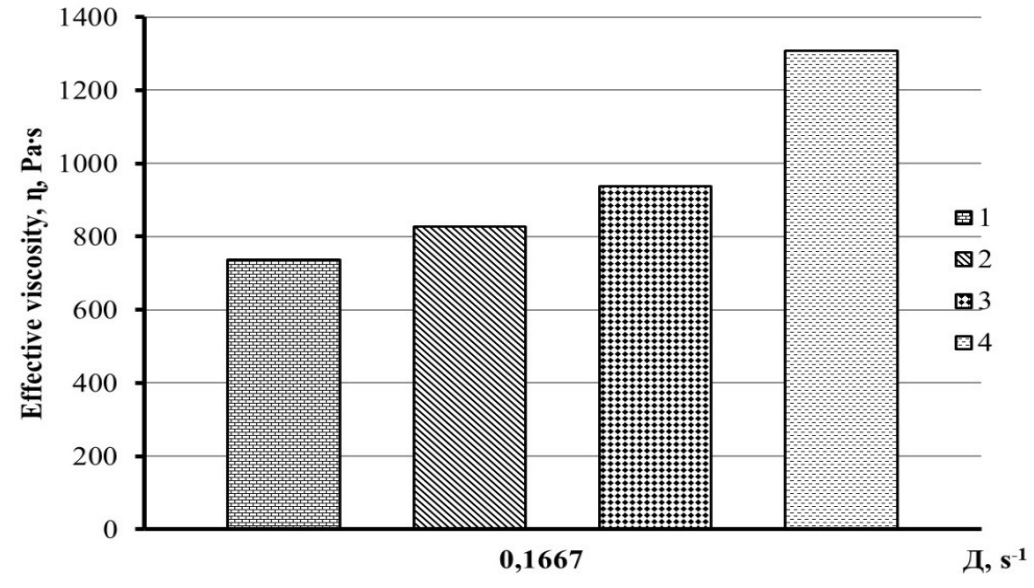

Fig. 1. Effect of the synbiotic complex on the changes of the effective viscosity in an unbroken structure, with the shear rate $0.1667 \mathrm{~s}^{-1}: 1$ - control; $2-2-10 \%$ of inulin and microencapsulated bifidobacteria; $3-20 \%$ of inulin and microencapsulated bifidobacteria; $4-30 \%$ of inulin and microencapsulated bifidobacteria 
of a synbiotic (microencapsulated bifidobacteria in a pectin matrix) supplemented with a prebiotic (inulin).

Inulin has a number of technological factors: it can substitute sugar and fat, modify the texture, stabilise the emulsion, is highly thermostable and hydrophilic. When added to a formulation, it does not affect the technological process, and improves the sense of sweetness of the food consumed. It forms opaque white creamy gel imitating the texture of fat, and improves the product's volume, texture, and taste $[16,17]$. Inulin has prebiotic properties. Its physiological value lies in normalising the intestinal microbiocoenosis by increasing useful microbiota and inhibiting pathogens.

Premised on the above, the studies focused on introduction of inulin into the recipe of fatty filling, where it replaced fat. The control sample was wafer biscuits Ananasni. In the course of a series of experiments, 10$40 \%$ of inulin was introduced into the formulation to

replace the equivalent amounts of fat. Addition of $40 \%$ of inulin made the filling too dense and too viscous, which prevented it from being evenly spread on the wafer sheets. That is why the mass fraction of inulin added to the recipe was, conventionally, 10, 20, and $30 \%$. The quantity of microorganisms included in the recipe was determined taking into account that the physiologically active microbial level in functional-purpose foods should be $10^{6}-10^{7} \mathrm{CFU} / \mathrm{g}$ intestinal contents.

During cooking, fatty filling behaves as a dense highly-concentrated two-phase dispersed system of the coagulation type. After cooling, when fat has crystallised, the filling acquires the coagulative and condensational structure. It should be noted that in the systems considered, the mechanostructural properties are mainly determined by the nature of the bonding between the phases, which are quite concentrated. A high-quality final product is only possible if its filling has the properties that allow spreading it evenly on wafer sheets and stabilising during maturation.

The main structural and mechanical characteristics of fat masses include their effective viscosity, shear stress (indicating a structure's breaking-down point), and plastic strength. The latter characterises how well the freshly-moulded products can tolerate further mechanical operations (glazing, wrapping, etc.). These properties are directly related to the specific features of the structure of these systems, their molecular interaction, and the ratio of their structural components.

One of the rheological characteristics determining the quality of filling is its viscosity, or internal friction, which is a measure of its resistance to flowing. Viscosity largely depends on the temperature of the mixture under study. A finished filling, before being smeared over wafer sheets, is kept in a tempering machine at $+30^{\circ} \mathrm{C}$.

The experiments were carried out on a rotational viscometer Rheotest 2, with the shear rate varying in the range $0.1667-72.9 \mathrm{~s}^{-1}$.

The results obtained show that with different mass fractions of inulin and bifidobacteria added to the filling, at the shear rate $0.1667 \mathrm{~s}^{-1}$, the effective viscosity in the control sample was $0.7 \mathrm{kPa} \cdot \mathrm{s}$. In the test samples with 10,20 , and $30 \%$ of inulin and bifidobacteria added, this parameter was, respectively, $0.8,0.9$, and $1.3 \mathrm{kPa} \cdot \mathrm{s}$ (Fig. $1)$. The higher effective viscosity in the test samples of filling may be due to the fact that the coagulation structure of the dispersed medium is formed by coalescing particles of the prebiotic fibre of inulin and powdered sugar through thin interfacial layers of the dispersed medium (fat). With smaller amounts of fat in the filling, the fat layers between particles become thinner and the structure and coagulation contacts stronger. That is why adding a synbiotic complex results in higher effective viscosity of the mass.

Cooling down wafer blocks is an important technological stage. A long cooling time of a filling means that a wafer block needs more time to cool down, or the cooling temperature should be lower. Such a time-taking cooling process can result in the dampening of wafers, because in the cooling cabinet, the air humidity is $92 \%$ or more. That is why it was so important to study the structure formation process in the wafer filling.

The physicomechanical properties of wafer filling are characterised by the critical share stress when the cone of a penetrometer plunges into the mass of the filling. It is an objective indicator of how a material resists crushing and deformation. That is why a material's penetrometric properties are related to its structural strength, which can be quantified by the value of the critical shear stress $\tau_{0}$

It has been studied how the effect of the synbiotic on the strength of the filling depends on the mass fraction of inulin (Table 1).

Table 1 - Dependence of the critical shear stress of the fatty filling on the duration of structure formation

\begin{tabular}{||c||c|c|c|c||}
\hline \multirow{2}{*}{ Time, min } & \multicolumn{3}{||}{$\begin{array}{l}\text { Shear stress } \tau, \mathrm{kPa}, \text { at a certain content of } \\
\text { inulin, \%, and microencapsulated bifido- } \\
\text { bacteria }\left(10^{7} \mathrm{CFU} / \mathrm{g}\right)\end{array}$} \\
\cline { 2 - 5 } & 0 (control) & $10 \%$ & $20 \%$ & $30 \%$ \\
\hline \hline 0 & 1.07 & 0.96 & 1.03 & 1.06 \\
\hline \hline 2 & 1.09 & 1.17 & 1.2 & 1.22 \\
\hline \hline 4 & 1.14 & 1.38 & 1.42 & 1.56 \\
\hline \hline 6 & 1.35 & 1.49 & 1.65 & 2.04 \\
\hline \hline 8 & 1.53 & 1.71 & 1.92 & 3.2 \\
\hline \hline 10 & 1.57 & 1.76 & 2.7 & - \\
\hline \hline 12 & 1.62 & 2.2 & - & - \\
\hline \hline 14 & 1.92 & - & - & - \\
\hline \hline
\end{tabular}

These findings make it clear that higher strength of the filling samples results in shorter maturation time of wafer blocks. Thus, in the control sample, the resting time is $14 \mathrm{~min}$, and in the test samples containing 10, 20, and $30 \%$ of inulin, this parameter is shorter: 12,8 , and 6 min respectively.

Thus, lowering the fat content in the filling and increasing the proportion of its solid phase make it stronger. This may be because the strength of coagulation structures is determined by the number and strength of contacts among solid particles in a certain unit of volume. Larger solid particles and thinner fat layers result in a stronger structure of the filling containing an increased mass fraction of inulin.

In the course of manufacturing fatty filling, highly important parameters are how strongly it adheres to the surface of the production equipment and how tightly a wafer sheet adjoins the filling. 


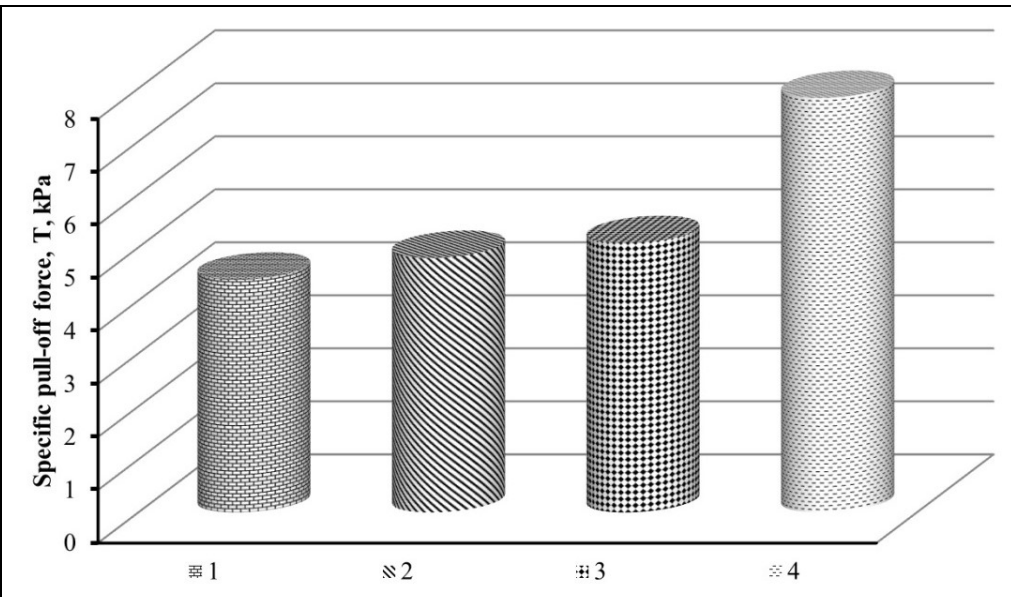

Fig. 2. Dependence of the specific pull-off force $T$ on the mass fraction of the synbiotic complex: 1 - control; $2-10 \%$ of inulin and microencapsulated bifidobacteria; $3-20 \%$ of inulin and microencapsulated bifidobacteria; $4-30 \%$ of inulin and microencapsulated bifidobacteria

Table 2 - Dependence of the density of the filling on the mass fraction of the synbiotic complex

\begin{tabular}{||l||c||}
\hline \hline \multicolumn{1}{|c|}{ Sample } & $\begin{array}{c}\text { Density of the } \\
\text { filling, } \mathrm{kg} / \mathrm{m}^{3}\end{array}$ \\
\hline \hline control & 772.01 \\
\hline \hline $10 \%$ of inulin and microcapsules & 820.5 \\
\hline \hline $20 \%$ of inulin and microcapsules & 869.64 \\
\hline \hline $30 \%$ of inulin and microcapsules & 882.68 \\
\hline \hline
\end{tabular}

Formation of the adhesive bond between the filling and the surface of wafer sheets is determined primarily by the rheological properties of the filling, the length and intensity of the previous contact, the temperatures of the wafer sheet and the filling, the way of pulling off, and the pull-off rate.

The tests were performed using an adhesion tester. Its operation was based on pulling a sheet off the mass of food. The forming rolls of smearing machines used in the confectionery industry are most often made of steel of the $3^{\text {rd }}$ grade of purity. So, in the experiments, a plate made of grade St3 steel was used as the boundary surface, its temperature being $29 \pm 2^{\circ} \mathrm{C}$ in all the tests. Some force was applied to the plate when putting it into contact with the mass of the filling. After some time necessary for the surfaces to stay in contact, the plate was pulled off the mass. Fig. 2 presents the data about the changes in the specific force $(T)$ of pulling the plate off the filling that contains the synbiotic complex.

The experimental results prove that the higher the proportion of inulin, the lower the specific pull-off force is, as compared with the control. Thus, in the control sample, it is $7.82 \mathrm{kPa}$, whereas in the ones with 10,20 , and $30 \%$ of inulin and microencapsulated bifidobacteria, this parameter

trol. is lower by 35,39 , and $44 \%$ respectively. Probably, the lower adhesion strength is due to the fact that the mass flowing gradually and slowly for some time fills in the dimples on the rough boundary surface, which, in turn, increases the contact area and, consequently, the adhesion strength. A higher mass fraction of inulin leads to more intense structure formation in the filling, which does not allow it to fill in the hollows in the relief of the surface and thus reduces the pull-off force of the fatty filling.

It has been established how the density of the filling changes with introduction of the synbiotic complex (Table 2).

As indicated by the findings, after adding the synbiotic complex, in the test samples of the filling, the proportion of fat responsible for aerating the food mass decreases. That is why the samples of filling become denser, as compared with the con-

Fatty filling is a structured mixed-phase dispersed system that includes the solid, liquid, and gaseous phase. The latter appears in the course of whipping the mass and is due to capturing and holding air bubbles. It has been found that the density parameter does not fully indicate the quality of the fatty filling: with the same value of the parameter, the filling can vary in quality, which depends, among other factors, on the size and number of the air bubbles the filling incorporates (Fig. $3 \mathrm{a}, \mathrm{b}, \mathrm{c}, \mathrm{d}$ ).

It has been studied how the value of the wafer filling density correlates with the characteristics of the air phase (the size and number of air bubbles in the filling). See Table 3.

As can be seen from these findings, with higher density of the filling, the number of the air bubbles decreases from 84 in the control sample to 46 in the sample with $30 \%$ of inulin and microencapsulated bifidobacte

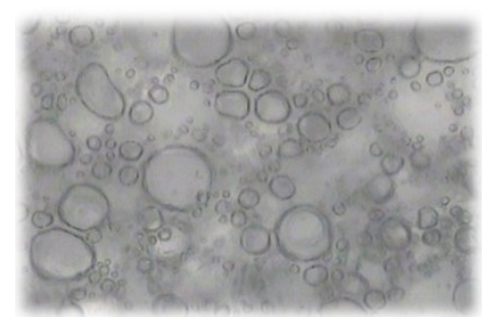

a

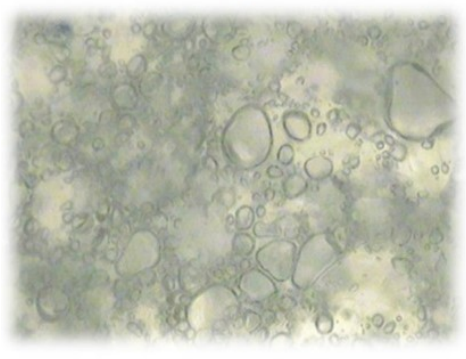

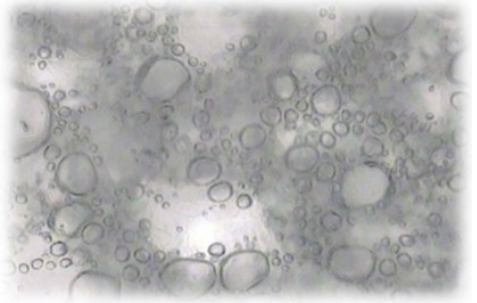

b

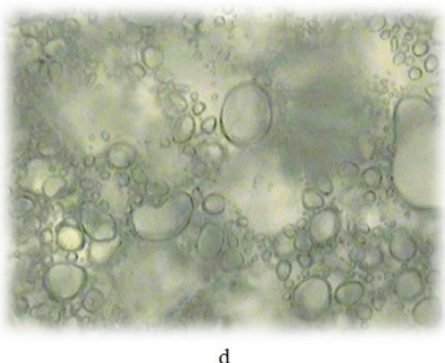

Fig. 3. Distribution of the air bubbles in the samples of wafer filling: a) control; b) with $10 \%$ of inulin and microencapsulated bifidobacteria; c) with $20 \%$ of inulin and microencapsulated bifidobacteria; d) with $30 \%$ of inulin and microencapsulated bifidobacteria

\section{$\square$}

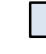


Table 3 - Dependence of the density of filling on the quantitative characteristics of the air phase

\begin{tabular}{||l||c||}
\hline \multicolumn{1}{|c||}{ Density, $\mathrm{kg} / \mathrm{m}^{3}$} & $\begin{array}{c}\text { Total quan- } \\
\text { tity of the } \\
\text { bubbles, pcs }\end{array}$ \\
\hline \hline 772 (control sample) & 84 \\
\hline \hline $\begin{array}{l}820 \text { (sample with } 10 \% \text { of inulin and } \\
\text { bifidobacteria) }\end{array}$ & 76 \\
\hline \hline $\begin{array}{l}870 \text { (sample with } 20 \% \text { of inulin and } \\
\text { bifidobacteria) }\end{array}$ & 55 \\
\hline \hline $\begin{array}{l}880 \text { (sample with } 30 \% \text { of inulin and } \\
\text { bifidobacteria) }\end{array}$ & 46 \\
\hline \hline
\end{tabular}

ria. The figures show that in the control, the bubbles are more evenly distributed throughout the sample. In the experimental samples, though, the bubbles are arranged in groups and there are areas with no air bubbles at all. Thus, the findings on the content of the air phase are in- direct evidence that fat contributes to aerating the food mass.

Based on the experimental results, formulations of the prototypes of final products have been developed and assessed by sensory parameters.

Field testing of the research results

The tests in the industrial environment of the companies Agrobiznes and Charivnyy Karavay have confirmed the effectiveness of the recipes and production technologies developed for wafer biscuits with synbioticcontaining fatty fillings.

Conclusions. Summarising the research conducted, one can conclude that the synbiotic complex introduced into the fatty filling formulation will allow improving the mechanostructural properties of the test samples of the filling. This will reduce the time the wafer blocks require to maturate, and increase the strength of the filling, which will have a positive effect on the quality of synbiotic-containing wafer products.

\section{REFERENCES}

1. Bondarenko A.V. Korektsiya dysbiotychnykh staniv i stabilizatsiya mikrobioty. Problemy bezperervnoyi medychnoyi osvity ta nauky. 2014. 2. P. 77-81.

2. Harasym J, Pejcz E. Development of a Sweet High-Fiber Wafer with Oat Bran. Cereal Foods World. 2015; 60(2).84-88

3. Şarba A.C., Mărghitaș L.A., Timar A. Study about differences between shortening used in wafer fillings and biscuit dough . Analele Universităţii din Oradea, Fascicula: Ecotoxicologie, Zootehnie şi Tehnologii de Industrie Alimntară. 2015;XIY/A: 291-296.

4. Syrokhman I.V., Pakhomova I.V. Polipshennya spozhyvnykh vlastyvostey novykh vafel'. Torhivlya, komertsiya, pidpryyemnytstvo. 2015. 18. P. 85-89.

5. Tarasenko I.V., Dorokhovych V.V., Ivanov S.A. Vplyv bezhlyutenovoho boroshna na vafel'ni vyroby ta perebih tekhnolohichnykh protsesiv. Prodovol'chi resursy. Seriya: Tekhnichni nauky. 2014. 3.P. 36-3.

6. Obolkina V. Vmist roslynnykh BAD u kondyters 'kykh vyrobakh. Prodovol'cha industriya APK. 2013. 1. P.37-38.

7. Fedorova D.V. Novi soloni vafel'ni vyroby «Krekisy rybni» z vykorystannyam ryboroslynnykh napivfabrykativ. TRAEKTORIA NAUKI. 2016. 4(9). P. 3.6-3.17.

8. Lozovaâ T.M. Ulučšenie potrebitel'skih svojstv vafel's ispol'zovaniem netradicionnogo syr'â. Vostočno-Evropejskij žurnal peredovyh tehnologij. 2014. 2/12. P.108-113.

9. Polivanov Ê.A. Rozrobka recepturi žirovoï načinki dlâ novogo vidu vafel'nih virobìv. Vìsnik Nacional'nogo Tehnì̌nogo Universitetu «HPÌ». Serìa : İnnovacìjnì doslìdžennâ u naukovih robotah studentìv. 2019. 15 (1340). P. 20-24.

10. Filippova E.V., Tarasenko N.A., Kurakina A.N. Razrabotka žirovoj načinki dlâ mučnyh konditerskih izdelij s ispol'zovaniem prebiotikov. Sovremennye problemy nauki i obrazovaniâ. 2015. 1-2. P.82-86.

11. Savenkova T.V., Soldatova E.A. Perspektivy ispol'zovaniâ muki podsolnečnoj polužirnoj v proizvodstve vafel'. Naučnye trudy SKFNCSVV. 2018. 20. P. 111-115.

12. Bobožonova G.A., Sorokina A.V. Razrabotka konditerskih izdelij obogaŝennyh belkom. HIPS. 2019. 1. P.57-65.

13. İorgačova K.G., et al. Tehnologiâ konditers'kogo virobnictva. Praktikum:navč. posibnik Odesa: Sìmeks-prìnt; 2011.

14. Korkač A.V., Ševcova D.P. Perspektivy ispol'zovaniâ sinbiotikov v tehnologii vafel'nyh izdelij. Tehnika i tehnologiâ pisevyh proizvodstv: materialy XII Meždunarodnoj naučno-tehničeskoj konferencii. Mogilev. 19-20 aprelâ. 2018. P.244-245.

15. Korkač A.V. Razrabotka žirovoj načinki dlâ vafel'nyh izdelij s ispol'zovaniem sinbiotikov. Prodovol'stvennaâ bezopasnost' v kontekste novyh idej i rešenij: materialy meždunarodnoj naučno-praktičeskoj konferencii. 2. 10 marta. Semej, Respublika Kazahstan. 2017. P. 29-32.

16. Litvâk V.V., Lukin N.D., Mihajlenko A.A., Kanarskij A.V. Morfologičeskie, strukturnye i degidratacionnye svojstva inulina «Raftilin GR». Vestnik Kazanskogo tehnologičeskogo universiteta. 2015. 18(1). P. 94-99.

17. Abed S.M., Ali A.H., Noman A., Bakry A.M. Inulin as prebiotics and its applications in food industry and human health: a review. International Journal of Agriculture Innovations and Research. 2016; 5(1): 88-97.

Г.В. Коркач, канд. техн. наук, доцент, E-mail: kor2007@ukr.net

К.Г. Іоргачова, д-р техн. наук, професор, E-mail: iorgachova@gmail.com О.М. Котузаки, канд. техн. наук, доцент, E-mail: elena1kotuzaki@gmail.com Одеська національна академія харчових технологій, вул.. Канатна, 112, Одеса, 65039, Украӥна

\section{ЗМІНА ВЛАСТИВОСТЕЙ БОРОШНЯНИХ КОНДИТЕРСЬКИХ ВИРОБІВ}

\section{3 СИНБІОТИКОМ}

\section{Анотація}

Одним із основних напрямів розвитку кондитерської галузі є створення нових виробів функиіональної спрямованості, які не тільки задовольняють потребу у харчуванні, але і будуть приносити користь організму. I тому актуальним є внесення до складу кондитерських виробів синбіотиків, які будуть сприяти як покращенню технологічного процесу виробництва, так і надавати фізіологічних властивостей готовим виробам. 
У роботі досліджено вплив синбіотичного комплексу, який складається із синбіотику - мікрокапсульованих біфідобактерій в пектинову матрицю, та додатково внесеного пребіотику - інуліну, на зміну структурномеханічних властивостей борошняних кондитерських виробів, зокрема, жирової начинки для вафельних виробів. Визначено масову частку інуліну, який вводили в начинку в кількості 10, 20 і $30 \%$, замінюючи ним еквівалентну кількість жиру. А кількість біфідобактерій, які вводились в рецептуру, визначали з урахуванням того, щэо фізіологічно активний рівень мікроорганізмів у функціональних продуктах повинен становити $10^{6} . . .10^{7} \mathrm{KУO/2} \mathrm{вмісту}$ кишечника.

Вивчено вплив синбіотику на структурно-механічні властивості жирової начинки: ефективну в'язкість, адгезійну міџність, граничну напругу зсуву та густину. Встановлено, що при внесенні синбіотику до складу жсрової начинки $i$ з підвищенням масової частки інуліну відбувається підвищення ефективної в'язкості в дослідних зразках начинки. Також внесення синбіотику сприяє підвищенню мічності дослідних зразків начинки, щчо призводить до скорочення тривалості вистоювання вафельних пластів. Так, час вистоювання пластів у контрольного зразку складає 14 хв, а у дослідних зразків з 10, 20 і 30 \% інуліну скорочується відповідно до 12, 8 та 6 хв. Встановлено, шо питома сила відриву з підвищенням масової частки інуліну знижується у порівнянні з контрольним зразком.

Дослідним шляхом виявлено зв'язок між показником густини вафельної начинки і характеристикою повітряної фази (розміром і кількістю пухирців повітря в начинці) і визначено, щзо з підвищенням густини начинки кількість пухириів повітря у зразках зменшується. Результати експериментальних досліджень показують доиільність використання синбіотику в технології вафельних виробів

Ключові слова: борошняні кондитерські вироби, мікрокапсульовані біфідобактерії, інулін, синбіотичний комплекс, жирова начинка, структурно-механічні властивості, вафлі.

\section{ЛІТЕРАТУРА}

1. Бондаренко А.В. Корекція дисбіотичних станів і стабілізація мікробіоти // Проблеми безперервної медичної освіти та науки. 2014. 2. С. 77-81.

2. Harasym J, Pejcz E. Development of a Sweet High-Fiber Wafer with Oat Bran //Cereal Foods World. 2015. 60(2).84-88.

3. Şarba A.C., Mărghitaş L.A., Timar A. Study about differences between shortening used in wafer fillings and biscuit dough // Analele Universităţii din Oradea, Fascicula: Ecotoxicologie, Zootehnie şi Tehnologii de Industrie Alimntară. 2015. Vol.XIY/A. 291-296.

4. Сирохман І.В., Пахомова І.В. Поліпшення споживних властивостей нових вафель // Торгівля, комериія, підприємницmво. 2015. Bun. 18. 85-89.

5. Тарасенко І.В., Дорохович В.В., Іванов С.А. Вплив безглютенового борошна на вафельні вироби та перебіг технологічних прочесів // Продовольчі ресурси. Серія: Технічні науки. 2014. № 3. 36-39.

6. Оболкіна В. Вміст рослинних БАД у кондитерських виробах // Продовольча індустрія АПК. 2013. № 1. 37-38.

7. Федорова Д.В. Нові солоні вафельні вироби «Крекіси рибні» з використанням риборослинних напівфабрикатів // TRAEKTORIA NAUKI. 2016. № 4(9). 3.6-3.17.

8. Лозовая Т.М. Улучшение потребительских свойств вафель с использованием нетрадиционного сырья // ВосточноЕвропейский журнал передовых технологий. 2014. № 2/12. 108-113.

9. Поливанов С.А. Розробка рецептури жирової начинки для нового виду вафельних виробів // Вісник Національного Технічного Університету «ХПІ». Серія : Інноваційні дослідження у наукових роботах студентів. 2019. № 15 (1340). 20-24.

10. Филиппова Е.В., Тарасенко Н.А., Куракина А.Н. Разработка жировой начинки для мучных кондитерских изделий с использованием пребиотиков // Современные проблемы науки и образования. 2015. № 1-2. 82-86.

11. Савенкова Т.В., Солдатова Е.А. Перспективы использования муки подсолнечной полужирной в производстве вафель // Научные труды СКФНЦСВВ. 2018. Том 20. 111-115.

12. Бобожонова Г.А., Сорокина А.В. Разработка кондитерских изделий обогащенных белком // ХИПС. 2019. № 1. 57-65.

13. Іоргачова К.Г., Макарова О.В., Гордієнко Л.В., Коркач Г.В. Технологія кондитерського виробництва. Практикум:навч. посібник Одеса: Сімекс-прінт, 2011. 208 с.

14. Коркач А.В., Шевиова Д.П. Перспективы использования синбиотиков в технологии вафельных изделий // Техника и технология пищевых производств: материалы ХІІ Международной научно-технической конференции, Могилев, 19 20 апреля 2018. 244-245.

15. Коркач А.В. Разработка жировой начинки для вафельных изделий с использованием синбиотиков // Продовольственная безопасность в контексте новых идей и решений: материалы международной научно-практической конференции, том 2, 10 марта, Семей, Республика Казахстан. 2017. 29-32.

16. Литвяк В.В., Лукин Н.Д., Михайленко А.А., Канарский А.В. Морфологические, структурные и дегидратационные свойства инулина «Raftilin GR» // Вестник Казанского технологического университета. 2015. № 18(1). 94-99.

17. Abed S.M., Ali A.H., Noman A., Bakry A.M. Inulin as prebiotics and its applications in food industry and human health: a review // International Journal of Agriculture Innovations and Research. 2016. № 5(1). 88-97.

Received 18.08.2020

Reviewed 17.09.2020

Revised $\quad 22.10 .2020$

Approved 05.11.2020

\section{Cite as Vancouver Citation Style}

Korkach H., Iorgachova E., Kotuzaki O. Modification properties of confectionary flour products with synbiotic. Grain products and mixed fodder's, 2020; 20 (4, 80): 18-23. Doi https://doi.org/

Cite as State Standard of Ukraine 8302:2015

Modification properties of confectionary flour products with synbiotic. / Korkach H. et al. // Grain Products and Mixed Fodder's. 2020. Vol. 20, Issue 4 (80). P. 18-23. DOI https://doi.org/ 